\title{
Examining the Factors Underlining the Inflationary Phenomenon in Ghana - A Dynamic ARDL Analysis
}

\author{
Emmanuel Atta Anaman \\ Department of Banking and Finance, School of Business, University of Education, Winneba, Ghana \\ Email address: \\ attaanamane@yahoo.com, eaanaman@uew.edu.gh

\section{To cite this article:} \\ Emmanuel Atta Anaman. Examining the Factors Underlining the Inflationary Phenomenon in Ghana - A Dynamic ARDL Analysis. Journal \\ of Business and Economic Development. Vol. 4, No. 2, 2019, pp. 53-63. doi: 10.11648/j.jbed.20190402.13
}

Received: May 15, 2019; Accepted: June 23, 2019; Published: July 1, 2019

\begin{abstract}
The phenomenon of inflation is one of the most widely discussed economic issues across the world and for this reason has continued to remain very relevant and visible within the policy domain. This is because it affects the economic fortunes of the principal actors within the economy from the low to the high income. This study adds to the existing literature on inflation by identifying the short and long run factors which influence its trajectory in the Ghanaian economy. The study adopts the Autoregressive Distributed Lag approach to comprehensively establish the long and short run determinants of inflation based on the data set spanning from 1979 to 2016 and the empirical analysis shows that price level is in the long run significantly determined by food crop production, crude oil prices, population, output of goods and services and money supply but in the short run the only variable which does not impact significantly on the price level variable is the interest rate proxied by the policy rate. It is also established that the system is able to correct about $60 \%$ of the deviations from its equilibrium position in every quarter. The main recommendation that emanates from the study is that policy makers instead of dealing with inflation mainly from the orthodox monetary perspective must also begin to pay more attention to the supply side issues in the economy.
\end{abstract}

Keywords: Bounds Test, Co Integration, Error Correction, Inflation and Stationarity

\section{Introduction}

In contemporary economic management, one of the most common and widely discussed subjects is the phenomenon of inflation and such in most countries of the world, controlling inflation is a major issue that engages the attention of academics, policy makers and even the general populace. This is because inflation has the tendency to create uncertainties in economies and thus has a profound impact on economic activities producing a cascading effect on the livelihoods of people. Inflation is therefore is seen as a considerable threat to economic prosperity in most countries for which reason different policy measures are conceived, designed and implemented to be able to deal with it.

In developing countries, the effects of inflation are accentuated by the fact that their economies are fragile and very susceptible to various types of pressures which lend them easily to precipitous situations like increases in prices of imports and inability to achieve the targeted revenue/expenditure framework or even adverse climatic factors which affect food production, all of which scenarios predispose the economies to acute inflationary spirals.

The effects of inflation are even more troubling in developing countries especially when one comes to terms with the fact that the vast majority of the world's poor are found in these regions. This therefore makes dealing with inflation more of an imperative than even before for the reason that a worsening inflationary situation is a veritable source of a further erosion of the purchasing power of the poor and drastic decline in their already low standards of living as well as a source of instability in economies of these countries around the world.

Aside of its debilitating effects on the purchasing power especially of the poor, it also has the tendency of adversely affecting the entire business environment and more specifically the businesses themselves by continuously escalating their costs of production and making it difficult for businesses to plan properly. The economic effects of inflation are summed 
up by Hossain and Islam. [1] In their words, inflation discourages investment, erodes savings and distorts the incentive structure of an economy by redirecting flow of capital into the unproductive sector of the economy and above all creates an inequitable distribution of income across an economy.

In Ghana, the phenomenon of inflation has continuously created problems for the managers of the economy across successive governments though a lot of efforts and attention have been directed at it with the view to stemming it. Historically, the rippling effect of inflation has tended to create a certain cyclical chain where as prices of goods and services are continuously on the rise, fixed wage and salary earners particularly those in government employment agitate for upward adjustment of their earnings which in turn triggers another round of inflation. This way inflation has become a conundrum and therefore very difficult to deal with.

There are a lot of factors traceable either domestically or externally which can be advanced to show the susceptibility of Ghana to inflation. The first factor is low productivity in the economy. It is argued that Ghana just as many of the developing countries has a work force whose productivity is very low and this goes a long way in creating supply side problems within the economy. The second is even more serious; that is that Ghana's economy is heavily import dependent, with huge imports ranging from foodstuffs to technological products exposing the country's economy to the vagaries of the international markets.

Besides these structural issues with the economy, problems arising out of fiscal and monetary management a lot of the times exacerbate the situation and create the conditions for inflation to take root and fester.

In the inflation literature there are several strands of perspectives on how it emerges in economies. These arguments can largely be compartmentalized into either supply side or demand side views.

A rich stock of researches on inflation, like these studies Kandil and Morsey, Lim andPapi, Bashir et al, Hashim et al, Hossain and Islam, Elgammal and Eissa and Akinbobola [17] has comprehensively explored the phenomenon of inflation by isolating the determinants from both supply and demand sides. Though most of these studies have been detailed, they tended to focus much more on factors from the fiscal and monetary sides of the economies within which they situated their researches to the detriment of structural factors. In Ghana, there have been a good number of studies which have sought to investigate inflation. Some of these earlier studies Kwakye, Chhibber and Shafik, Sowa and Kwakye [810] appear to suffer from some methodological challenges in the sense that all of these were done within a static estimation framework and therefore oblivious of the fact that static estimation especially in relation to time series data has a high likelihood of generating spurious results. In addition, they never dealt with the possibility of separating the short and long run effects as a better technique for understanding the causes of inflation. Though some of the recent studies in Ghana - Gyebi and Boafo, Enu and Havi, Chiaraah and
Nkegbe [11-13] have attempted to deal with methodological challenges of the earlier studies, all the relevant structural and the supply side factors have not appropriately been highlighted as they should. Besides, the most recent study by Acquah-Sam [14] also fails to address all the important pitfalls of the earlier studies. In the light of this, we in this study attempt to employ the ARDL dynamic approach to comprehensively examine the effects of all the major elements which are suspected to fuel inflation in Ghana and pose the following relevant questions; how does food production influence inflation? In what ways do crude oil prices affect the inflationary trends? Does population growth influence the inflationary trajectory in Ghana? Again are domestic factors more prominent than external factors in the inflationary movements in the Ghanaian economy? We therefore seek answers to these questions among other pertinent issues that we would want to address in this study.

The study therefore attempts to comprehensively uncover the determinants of inflation in Ghana by applying up to date data and current econometric tools.

The rest of the paper is organized as follows; Section 2 deals with historical analysis of inflationary trends in Ghana situating it within successive policy regimes. Section 3 concerns itself with the review of the literature pertaining to inflation whilst Section 4 delves into the issues of methodology, data, and empirical model as well as the framework for analysis. The next Section, 5 highlights the results from the analysis and proceeds to discuss them in the context of the prevailing literature. The last part of the paper, Section 6 sums up the study and presents the conclusions and policy implications.

\section{A Survey of Inflation Policy Thrust and Performance in Ghana}

The historical account of the phenomenon of inflation in Ghana cannot properly be done without discussing the economic policies implemented by successive governments in Ghana. In other words the phenomenon of inflation is inextricably linked with the kind of the policies pursued by various governments.

The battle against inflation in Ghana began just after the attainment of independence when the government at the time in line with prevailing development orthodoxy adopted the 'big push' concept and thus embarked on massive state investments in all the sectors of the Ghanaian economy. Social and economic infrastructure which was determined to be critical to the growth and development in Ghana were financed by state and it is therefore not very surprising that the country started experiencing signs of inflationary pressures in the mid-sixties. This situation was worsened by the declining receipts from exports as well as low domestic revenues.

The policies during the period of military interregnum from the early 1970s added fillip and momentum to the inflationary situation and seriously undermined economic growth and development. Some of the policies which added impetus to the 
inflationary pressures in the economy were price and import controls as well exchange rate controls. These led to the systematic distortion of the incentive structure of the economy and precipitated a prolonged period of supply shocks. Thus in an era described as a period of economic dirigisme in the literature, the military governments resorted to heavy domestic borrowing against the background of dwindling revenue base resulting from low capacity utilization in industries and declining productivity in the agricultural sector in order to get the Ghanaian economy going especially when during the period, external financial support had reduced dramatically. It is to be noted that the period also coincided with the petroleum crisis arising out of a turbulent international political situation especially in the Middle East which stoked further the rates of inflation. The inflationary situation in the country was so serious that there emerged a cliché, 'Kalabule' in the Ghanaian economic lexicon which was a characterization of the prevailing rapidly increasing costs of goods and services worsened by the activities of the market women. Inflation therefore rose through the roof and reached high levels and even more further undermined the domestic production and overall business environment.

The vestiges of the some of the economic problems experienced in the 70s persisted in the Ghanaian economy even after the country had returned to constitutional rule in 1979 and into the early 1980s, the country recorded very high inflation rates. The inflationary spiral was compounded by adverse climatic factors which occasioned excruciating periods of drought with the accompanying acute decline in the country's food production within the period. This is evidenced by the rates of $117 \%$ and $123 \%$ registered in 1981 and 1983 respectively. However, in the mid-1980s the inflationary pressures eased up as the country started deriving some dividends from the Economic Recovery Programme (ERP) launched in 1983. The ERP brought in its wake key economic reforms like removal of the system of controls, market liberalization and recapitalization and the revamping of the banking sector leading to the restoration of the positive growth trajectory of the economy.

With the return to the constitutional rule again in 1992 , inflationary pressures began to resurge as high government expenditures financed mainly through domestic borrowing especially in election years contributed to rising inflationary rates. This situation, over the last twenty six years appear to have become procyclical with electioneering periods in the country and led to high rates of inflation.

It must be noted that all throughout these periods, the Bank of Ghana employed the monetary targeting framework as the strategy for fighting inflation and under this the bank used monetary policy tools to temper inflationary pressures within the economy. In 2006, however, the Bank of Ghana abandoned the monetary targeting approach to dealing with inflation and adopted the inflation targeting framework where the Bank sets inflation targets to be achieved within a given period. In spite of the change in strategy, getting inflation rates to stay within reasonable levels and sustaining it has been a big challenge to the managers of the economy as deficit financing has become an avenue through which government is able to pursue a good chunk of its programmed projects especially when revenues always lag far behind the expenditures. It must be noted though that despite the fact that government and BOG have not been able to completely rein in inflation, between 2000 and 2018 inflation surged above the $20 \%$ mark only twice in 2001 and 2003. What is clear however about this period is the dominance of the fiscal policy over monetary policy making the inflation targets difficult to achieve by the Bank of Ghana.

The table below provides a snapshot of the macroeconomic picture in Ghana and this makes it easier to understand the trends in Ghana's economy over the years.

Table 1. A brief survey of macroeconomic indices in Ghana (1995-2016).

\begin{tabular}{llll}
\hline Year & Ms Growth(\%) & Exchange rate & Inflation \\
\hline 1995 & 43.17 & 0.14 & 59.46 \\
1996 & 39.20 & 0.18 & 46.56 \\
1997 & 44.09 & 0.23 & 27.89 \\
1998 & 17.49 & 0.23 & 14.62 \\
1999 & 25.42 & 0.35 & 12.41 \\
2000 & 54.24 & 0.70 & 25.19 \\
2001 & 31.69 & 0.73 & 32.91 \\
2002 & 48.85 & 0.84 & 14.82 \\
2003 & 37.23 & 0.89 & 26.67 \\
2004 & 27.44 & 0.91 & 12.62 \\
2005 & 14.10 & 0.91 & 15.12 \\
2006 & 38.8 & 0.92 & 10.92 \\
2007 & 35.9 & 0.97 & 10.73 \\
2008 & 40.2 & 1.21 & 16.52 \\
2009 & 26.9 & 1.42 & 19.25 \\
2010 & 27.2 & 1.47 & 10.71 \\
2011 & 37.1 & 1.55 & 8.73 \\
2012 & 24.3 & 1.88 & 9.16 \\
2013 & 17.7 & 2.20 & 11.61 \\
2014 & 36.8 & 3.20 & 15.15 \\
2015 & 25.57 & 3.68 & 17.15 \\
2016 & 22.50 & 3.92 & 17.47 \\
\hline
\end{tabular}

Source: World Bank, IMF and Bank of Ghana databases

\section{Review of Literature}

There is a vast array of literature which attempts to explain the phenomenon of inflation from various perspectives and one view which clearly delineates the issues is that proffered by Lim and Papi [3]. According to them, the issue of inflation can generally be explained from three angles, the monetary, public finance and structural approaches. In the monetary side explanation, it is assumed that there is a stable demand for real money balances conditioned by two factors, real income and returns on assets and that an expansionary monetary pursued within the context of aggregate supply constraints triggers an inflationary spiral. The public finance approach emphasizes the monetization of deficits as a major cause of inflationary pressures in economies.. Under this, it is argued that in an economy where there are limits on both domestic and external borrowing, recourse to monetization of the deficits leads to inflation. The last explanation highlights three issues; the relationship between exchange rate and domestic prices, marked up prices due to the oligopolistic structure of prevailing industries and wage pressures resulting mainly from inflationary expectations as factors 
which largely underline the inflationary process.

Gyebi and Boafo [11] express sentiments which are similar to those of Lim [3]. They also isolate three theoretical strands in explaining the phenomenon of inflation. These are the monetary, structuralist and the Keynesian theories. In their words, the monetary view is anchored on Milton Friedman's assertion that inflation is always and everywhere a monetary phenomenon, a position he uses the quantity theory of money to illustrate and justify. From the structuralist point of view, according to Gyebi and Boafo [11], the main argument advanced is that in developing countries especially, there exist structural rigidities and bottlenecks be they economic, political or institutional factors which lead to very low elasticity of supply of goods especially agricultural products which ultimately fuel inflation. The third position espoused by them is called the Keynesian theory. The thrust of this position is that pressure for increased wages usually mounted by labour unions and yielded to by employers in the economy especially without commensurate expansion in aggregate output inevitably leads to inflation. Again, the employers /producers as a result of the upwards adjustment of wages would then also mark up their prices, thereby creating a wage-price inflationary spiral.

With these theoretical propositions, there is an affirmation that factors which are responsible for inflation emanate from both the demand and supply sides of an economy. In the literature one of the most dominant factors discussed is the role of exchange rate on the inflationary process. According to Sanusi [15], the effect of exchange rate on the inflationary process is in two stages; from exchange rate to import prices and then from import prices to consumer prices but effected through three channels; prices of imported consumption goods, domestically produced goods which are priced in exchange rate equivalence and then prices of imported intermediate goods. In the view of Sahminan [16] the first two channels lead to a direct effect of the exchange rate on prices whilst in the third, the exchange rate influences domestic prices less directly by affecting the costs of production in the economy.

Another major factor which is encountered in the discussion on the causes of inflation is the growth in money supply. It is normally argued that a rapid growth in money supply reinforces demand-side pressures in the economy and gives momentum to inflationary movements within economies. This view is strongly canvassed by these studies;Sargent and Wallace, Montiel [17, 18] among others. This group which advances this demand side argument usually point to the monetary financing of fiscal deficits as the biggest cause of monetary growth in economies.

Again in a lot of the developing countries, the level of agricultural output is very crucial in shaping up price movements in the economy. This is because a big portion of household expenditures goes into the purchase of foodstuff for consumption. Therefore a low agricultural output has the effect of creating supply side problems and invariably generating upward pressure on food prices in the economy which are very prominent in the consumer basket and hence profoundly influence inflationary movements. This position is buttressed
Akinbobola [7] when he alludes to harsh weather conditions and attendant crop failures as significant contributors to the inflationary trends.

Apart from all these factors enumerated and discussed in the literature, one other issue which is sometimes flagged is the susceptibility of an economy especially that of developing countries to volatility in the prices of crude oil on world markets. It is a well-known fact that the economies of lot countries are very dependent on crude and indeed are affected by cascading effect of the prices of crude on economic activities.. To that extent, domestic prices of goods and services are therefore influenced by these movements. This is especially true of developing countries like Ghana which are hardly able to withstand these shocks and are thus always at the receiving end of their repercussions.

Quite a lot of studies on inflation exist in the literature and these have provided both theoretical and empirical foundations for the current study.

Lim and Papi [3] embarked on an econometric analysis of the determinants of inflation in Turkey using a multi-sector macroeconomic dynamic framework with data spanning from 1970 to 1995 , they found that monetary variables are particularly very important in the inflationary movements in Turkey and that public sector deficits have a direct effect on inflation in Turkey. Bashir et al [4] focused on isolating the determinants of inflation in Pakistan using the Johassen co integration approach, based on data set 1972-2010. The empirical results showed that money supply, government expenditure and imports do positively affect inflation whereas government revenues tend to reduce inflationary movements. In the short run however, the lags of consumer price index and government revenue reinforce inflation.

The study by Hashim et al [5] concentrated on identifying the determinants of inflation in Malaysia. Using a simple multiple regression approach, the authors found that government expenditure, imports, interest rates and gross domestic product (GDP) are all negatively related to inflation. However, money supply was identified to have a positive effect on inflation.

Hossain and Islam [1] sought to embark on the econometric analysis of the determinants of inflation in Bangladesh based the data set from 1990 to 2010 and employed the OLS to unravel the relationships between inflation and money supply, nominal exchange rate, fiscal deficit and interest rate. From the estimation, they also found a positive effect of money supply on inflation but interest rate, nominal exchange rate and fiscal deficit were estimated not to significantly affect inflation.

Another empirical study authored by Akinbobola [7] set out to examine the dynamics of money supply, exchange rate and inflation in Nigeria drawing his sample from 1986 to 2008. By employing the vector error correction approach, the author uncovered that in the long run, both money supply and exchange rate have a negative effect on inflation but real output and foreign prices directly affect inflation. In the short-run, inflation in the first period and broad money supply significantly affect inflation whilst variance decomposition shows that money supply is the most 
important innovation which affects inflationary movements after own innovation.

The study by Elgammal and Eissa [6] was centered on identifying the key determinants of inflation and monetary policy in Vietnam. The authors employed the vector error correction approach to show that inflation, exchange rate and real income were significantly related in the long run. In the short run, they found that the exchange rate pass through was very strong.

Chiaraah and Nkegbe [13] preoccupied themselves with examining the dynamic nexus among economic growth, money growth, exchange rate and inflation and discovered that in the long run money supply, foreign price and real income significantly influence inflation in Ghana. However the long run estimates showed that exchange rate does not impact on inflation.

In the literature other studies have endeavoured to carry on the process of isolating the causes of inflation in Ghana.

Gyebi and Boafo [11] studied the macroeconomic determinants of inflation in Ghana from 1990 to 2009 and using the Ordinary Least Squares approach came to the conclusion that real output and money supply are the key variables which significantly affect inflation.

In their study, Enu and Havi [12], set themselves the main objective of identifying the macroeconomic determinants of inflation in Ghana by employing a co-integration and error correction analysis. The empirical model that they used encompassed population growth rate, foreign aid, foreign direct investment, agriculture and service outputs.. Their regression estimates indicated that there exists both short and long run relationship between the inflation and the rest of the variables.

Another study on the Ghanaian situation Acquah-Sam [14], assessed the influencers of inflation in Ghana. Deviating from the previous studies, this study adopted the structural equation modelling (SEM)-path analysis methodology with multiple linear regression equation to conclude that the interest rate variable exerts a positive effect on inflation. The estimation result however proved that GDP growth, foreign direct investments and gross fixed investment do not significantly impact on inflation in Ghana.

\section{Methodology}

\subsection{Specification of Empirical Model}

The basis of the model for the study is derived from Lissovolik [19]. According to Lissovolik [19], at any point in time, the price level that prevails in a given economy can be defined as a weighted average of the price of goods which can be sold only on domestic markets and those which are traded with foreign countries.

Mathematically,

$$
\operatorname{Ln} P_{t}=\alpha \operatorname{Ln} P_{t}^{T}+(1-\alpha) \operatorname{Ln} P_{t}^{N},
$$

where

$\operatorname{LnP} P_{t}$ is a definition of the overall price that obtains in an economy

$\operatorname{Ln} P_{t}^{T}$ represents the price of tradable goods (goods traded with foreign countries) whilst

$\operatorname{Ln} P_{t}^{N}$ denotes the price of non-tradables (goods sold on the domestic market) and

$\alpha$ is the proportion of tradable goods in total expenditure.

By its definition, $\operatorname{Ln} P_{t}^{T}$ is determined primarily by two factors especially in small open economies; these are the prevailing world market prices $\left(\operatorname{Ln} P_{t}^{W}\right)$ and the exchange rates $\left(L n E_{\mathrm{t}}\right)$ at any given time.

Hence,

$$
\operatorname{Ln} P_{t}^{T}=\operatorname{Ln} P_{t}^{W}+\operatorname{Ln} \operatorname{Exr}_{t}
$$

But from theory, prices of non-tradables are determined by the prevailing money market situation that is the state of demand for money in relation to money supply. Thus mathematically,

$$
\operatorname{Ln} P_{t}^{N}=P\left(\operatorname{Ln}\left(M_{t}^{S}\right)-\operatorname{Ln}\left(M_{t}^{D}\right) / P_{t}\right.
$$

Again

$\operatorname{Ln}\left(\mathrm{M}_{\mathrm{t}}^{\mathrm{D}}\right) / \mathrm{P}_{\mathrm{t}}=\mu_{0}+\mu_{1} \operatorname{LnY}_{\mathrm{t}}+\mu_{2} \mathrm{r}_{\mathrm{t}}+\mu_{2} \mathrm{P}_{\mathrm{t}-1}+\mu_{3} \mathrm{P}_{\mathrm{t}} \mathrm{p}^{\mathrm{p}}+\mu_{4} \mathrm{~F}_{\mathrm{t}}^{\mathrm{p}}$

from which we say that

$$
\operatorname{Ln} P_{t}^{N}=\pi\left(\operatorname{Ln}\left(M_{t}^{S}\right)-\left(\mu_{0}+\mu_{1} \operatorname{Ln} Y_{t}+\mu_{2} r_{t}+\mu_{2} P_{t-1}+\mu_{3} P_{t *}^{p}+\mu_{4}\right.\right.
$$

where

$\operatorname{Ln} Y_{t}$ represents real industrial output, $\mu_{3} P_{p^{*}}$ denotes population growth and $\mu_{4} F^{p c}$ defines the food production.

Now having regard to the fact of the importance of crude oil to the economy of Ghana, we redefine $\operatorname{Ln} P_{t}^{W}$.

Therefore

$$
\operatorname{Ln} P_{t}^{W}=f\left(\operatorname{Ln} C^{p}, \operatorname{Ln} I^{m}\right)
$$

$\operatorname{LnC} C^{p}$ is the price of crude oil on the world market and

$L n I^{m}$ describes the price of other imported goods on the world market.

Based on the above derivations, we finally define general prices $P_{t}$ in terms of all other factors identified.

Hence

$$
P_{t}=f\left(M_{t}^{S}, Y_{t}, C_{t}^{p}, I_{t}^{m}, E x r_{t}, r_{t}, P_{t}^{p} * F_{t}^{p c}\right) .
$$

Our empirical model would be based on

$$
\Delta P_{t}=f\left(\Delta M_{t}^{S}, \Delta Y_{t}, \Delta C_{t}^{p}, \Delta I_{t}^{m}, \Delta E x r_{t}, \Delta r_{t}, \Delta P_{t}^{p}{ }_{*} \Delta F_{t}^{p c}\right)
$$

Having obtained the model to be estimated, we proceed to test for the stationarity status of the variables of interest. This is because it is established that most time series data are nonstationary and that when regressions are done without taking care of their time variant or non-stationary properties they likely generate spurious results. The procedure employed therefore involves determining whether

$$
Y t=\alpha_{0}+\alpha_{1} t+\alpha_{2} \ln y_{t-1}+\sum_{i=2}^{p} \beta \Delta \ln y t+u t
$$


follows an AR stationary and therefore yield spurious results when the conventional and orthodox estimation techniques are employed to process them. Granger and Newbold [20] put it more succinctly by arguing that econometric estimations using non-stationary data lead to spurious results. According to Harris and Sollis [21], non-stationary time series have different means at different points in time and their variances increase as their sample sizes are increased. It is this characteristic of the time series which distorts empirical estimations and leads to the generation of spurious results. Hence to derive the right estimates, the nonstationary properties have to be dealt with.

The test for stationarity involves the determination as to whether or not a given series contains unit roots. We do this by means of the Augmented Dickey Fuller (ADF) test. The typical ADF test is formulated in the following way;

$\mathrm{H}_{0}$ : the series does contain unit roots and $\mathrm{H}_{1}$ : the series does not contain unit roots. If in this test of hypothesis, if we fail to accept the null hypothesis, it implies the series are stationary. On the other hand, if we fail to reject the null hypothesis, then the conclusion is that the series is non stationary at levels and hence the non-stationary attributes would have to be removed. In the case when the latter prevails, then the series can be make stationary by a technique called differencing. In empirical analysis, the number times the series is differenced to make it stationary is referred to as the order of integration. The test of stationarity is necessary because the ARDL cannot take variables which are $I(2)$ and above though it can handle a mixture of $\mathrm{I}(0)$ and $\mathrm{I}(1)$ variables.

After the test of stationarity of the variables, we proceed to determine whether there exists at least a co integrating relationship among the variables in equation 7 . In words of the Thomas [22], when variables are co integrated it implies that there is a linear combination of these variables which is stationary. Stated in another way, when variables are co integrated, then there exists a long run equilibrium relationship among them and that for such variables, they may momentarily drift apart but eventually they converge and drift towards a certain desired equilibrium position in the long run. These views are reinforced in the study, Anaman et al [23] when they assert that the implicit meaning of co integration is the existence of a statistically significant relationship among some economic variables with a defined linear combination which is stationary. In the test for co integration in this paper, we employ the Pesaran bounds approach rather than the two step Engle Granger or the Johassen methods which are not suited to dealing with variables which are not strictly $\mathrm{I}(1)$. The advantage that the ARDL approach has lies in the fact that aside of its flexibility in being able to handle variables of different orders of integration Pesaran and Pesaran [24], it is able to use a simple linear transformation to derive the error correction model Banerjee et al [25].

Generally we would construct our ADRL model as follows:

$\Delta C P I_{t}=\lambda_{0}+\lambda_{1} C P I_{t-1}+\lambda_{2} M s_{t-1}+\lambda_{3} G D P 2_{t-1}+\lambda_{4} C^{p}{ }_{t-1}+\lambda_{5} I^{m}{ }_{t-}$

$$
\begin{gathered}
{ }_{1}+\lambda_{6} \operatorname{Exr}_{t-1}+\lambda_{7} r_{t-1}+\lambda_{8} P^{p}{ }_{t-1}+\lambda_{9} F P^{c}{ }_{t-1}+\psi_{1} \Delta C P I_{t-i}+\psi \\
{ }_{2} \Delta M^{5}{ }_{t-i}+\psi_{3} \Delta G D P_{t-i}+\psi_{4} \Delta C^{p}{ }_{t-i}+\psi_{5} \Delta I^{m}{ }_{t-i}+\psi_{6} \Delta \operatorname{Exr}_{t-i}+ \\
\psi_{7} \Delta r_{t-i}+\psi_{8} \Delta P^{p}{ }_{t-i}+\psi_{9} \Delta F^{p}{ }_{t-i}+\delta E C M_{t-1}+\mu_{t} .
\end{gathered}
$$

In this formulation, the $\lambda$ s represent the expected long run coefficients whereas the $\psi \mathrm{s}$ stand for the short run coefficients.

Indeed according to Frimpong and Oteng-Abayie [26], the ARDL estimation technique has some advantages over other dynamic modelling methods in the sense that apart from being simple, it allows the co integration relationship to be estimated and established using OLS unlike the other multivariate approaches and more importantly accommodates a mixture of $\mathrm{I}(0)$ and $\mathrm{I}(1)$ variables in the estimation process.

To test for co integration, we determine which of these two hypotheses prevails;

$$
\mathrm{H}_{0}: \lambda_{1}=\lambda_{2}=\lambda_{3}=\lambda_{4}=\lambda_{5}=\lambda_{6}=\lambda_{7}=\lambda_{8}=\lambda_{9}=0 \text { and }
$$

$\mathrm{H}_{1}: \lambda_{1} \neq \lambda_{2} \neq \lambda_{3} \neq \lambda_{4} \neq \lambda_{5} \neq \lambda_{6} \neq \lambda_{7} \neq \lambda_{8} \neq \lambda_{9} \neq 0$

If we fail to reject the null hypothesis, it implies that there is no long run equilibrium relationship between the price level variable and the other variables. However, if we fail to accept the null hypothesis meaning is that alternative hypothesis is upheld, then the conclusion is that there exists a long run equilibrium relationship between the price level variable and the other variables in the model., We thus proceed to compare the F-statistic derived from the estimated long run equation with the critical values provided for in the Pesaran table at $\mathrm{I}(0)$ and $\mathrm{I}(1)$ respectively because the ARDL model handles variables at $\mathrm{I}(0)$ and $\mathrm{I}(1)$. The rule of the thumb in this case is that if $\mathrm{F}$ calculated is less the value at $\mathrm{I}(0)$, we fail to reject Ho and conclude that there is no co integrating relationship. On the other hand if the $F$ calculated is greater than the value at I(1) then we rather fail to accept the null hypothesis and conclude that there is exists a long run equilibrium relationship between price level and the other variables. The last possibility is when the $\mathrm{F}$ calculated lies between the values at $\mathrm{I}(0)$ and $\mathrm{I}(1)$ in which case there is an indeterminate situation. Once long run relationship is established, we satisfy ourselves by determining whether or not the model is stable using the CUSUM diagnostic test.

\subsection{Data for Study}

The data set for the study was extracted mainly from International Monetary Fund databases though some were obtained from some statutory institutions like Bank of Ghana (BOG) and Ghana Statistical Service (GSS) databases.. All the variables are entered in annual forms. The variables of interest in this study are price level measured by the consumer price index (CPI), the exchange rate(Ex_r), gross domestic product (GDP) defining domestic goods and services, Imports of goods and services into the Ghanaian economy(Im), world market prices of crude oil $(\mathrm{Cp})$, the policy rate as set Bank of Ghana(r), the total population(Pp), the quantum of money supply(Ms) in the economy and total cereal 
production(Fpc) as a proxy for food production in the country. The data set spanned from 1979 to 2016 .

\section{Analysis of Data}

\section{Stationarity Test Results}

In this study, we employ the ADF tests for stationarity to determine the order of integration of all variables. However, since we dealing with an ARDL model, it is required that none of the variables in the model has an order of integration more than one which means that even if one of the variables is I(2) or even higher, then we cannot proceed with the ARDL estimation. In the table below, we present our stationarity test results. In determining the stationarity status of the variables, we test $\mathrm{H}_{0}$ : the series has unit roots against $\mathrm{H}_{1}$ : the series has no unit roots.

The table below shows the stationarity test
Table 2. Intermediate ADF test results.

\begin{tabular}{|c|c|c|c|c|}
\hline Series & Prob. & Lag & Max Lag & Obs \\
\hline $\mathrm{D}$ (LMS) & 0.0005 & 0 & 8 & 36 \\
\hline $\mathrm{D}\left(\mathrm{LI}^{\mathrm{M}}\right)$ & 0.0004 & 1 & 8 & 35 \\
\hline $\mathrm{D}\left(\mathrm{LP}^{\mathrm{P}^{*}}\right)$ & 0.0068 & 7 & 8 & 35 \\
\hline $\mathrm{D}\left(\mathrm{LFP}^{\mathrm{C}}\right)$ & 0.0000 & 0 & 8 & 36 \\
\hline D(LGDP2) & 0.0781 & 6 & 8 & 30 \\
\hline $\mathrm{D}\left(\mathrm{LC}^{\mathrm{P}}\right)$ & 0.0000 & 0 & 8 & 36 \\
\hline D(LCPI) & 0.0015 & 0 & 8 & 36 \\
\hline $\mathrm{D}(\mathrm{R})$ & 0.0000 & 0 & 8 & 36 \\
\hline D(LEX_r) & 0.0001 & 0 & 8 & 36 \\
\hline
\end{tabular}

From the above results, we conclude that all the variables in model are either $\mathrm{I}(0)$ or $\mathrm{I}(1)$ and none is $\mathrm{I}(2)$ since the variables were all tested at their first differences and can thus be entered into our ARDL model.

Next we determine the optimal lag structure for our model by using the lag selection criteria. The lag structure selection results are shown below.

Table 3. Lag structure selection.

\begin{tabular}{|c|c|c|c|c|c|c|}
\hline \multicolumn{7}{|c|}{ Included observations: 29} \\
\hline Lag & $\log \mathbf{L}$ & LR & FPE & AIC & SC & HQ \\
\hline 0 & 50.78763 & NA & 0.003107 & -2.950871 & -2.573686 & -2.832741 \\
\hline 1 & 53.83136 & $4.198254^{*}$ & $0.002716^{*}$ & $-3.091818^{*}$ & $-2.667485^{*}$ & $-2.958922 *$ \\
\hline 2 & 53.96568 & 0.175999 & 0.002907 & -3.032116 & -2.560634 & -2.884454 \\
\hline 3 & 54.31420 & 0.432652 & 0.003073 & -2.987186 & -2.468557 & -2.824758 \\
\hline 4 & 54.33183 & 0.020669 & 0.003331 & -2.919437 & -2.353659 & -2.742242 \\
\hline 5 & 54.68582 & 0.390606 & 0.003538 & -2.874884 & -2.261958 & -2.682923 \\
\hline 7 & 57.83415 & 2.978097 & 0.003409 & -2.954079 & -2.246857 & -2.732586 \\
\hline 8 & 58.28281 & 0.402246 & 0.003640 & -2.916056 & -2.161686 & -2.679797 \\
\hline
\end{tabular}

* indicates lag order selected by the criterion

LR: sequential modified LR test statistic (each test at $5 \%$ level)

FPE: Final prediction error

AIC: Akaike information criterion

SC: Schwarz information criterion

HQ: Hannan-Quinn information criterion

The optimal lag structure test results indicate that all the different criteria identify lag one as the optimal lag structure for our analysis. Hence all our estimations are done with lag one for all the variables in the model.

To be sure that the variables in our model are not correlated we employ the Breusch-Godfrey test for serial correlation. In this, we test $\mathrm{H}_{0}$ : there is no serial correlation in the series as opposed to $\mathrm{H}_{1}$ : there is serial correlation among the variables. The test results are presented below.

Table 4. Tests for Serial Correlation

\begin{tabular}{llll}
\hline F-statistic & 0.023063 & Prob. F(1, 16) & 0.8812 \\
Obs*R-squared & 0.051816 & Prob. Chi-Square(1) & 0.8199 \\
\hline
\end{tabular}

From the calculated $\mathrm{F}$ value above, we fail to reject the null hypothesis, meaning that there is no evidence of serial correlation in the model.

Next we perform a stability test to make sure that the model is reasonably stable using the CUSUM test. The test results are depicted in the diagram below

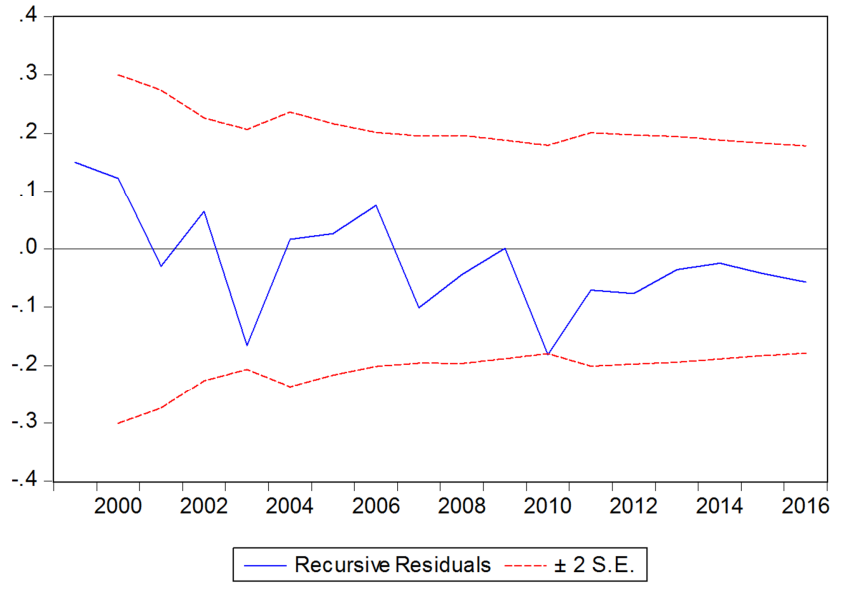

Figure 1. CUSUM test for stability.

Since the model does not trend out of the established boundaries in the graph above, we safely conclude that the model is stable. This thus enables us to go to the next stage of the estimation.

We are therefore able to continue with the ARDL 
estimation by testing for co integration between the price level variable(CPI) and the other variables in the model using the bounds method. The results of the bounds tests are presented in the table below.

Table 5. ARDL Bounds tests for co integration.

\begin{tabular}{llll}
\hline Wald Test: & & & \\
\hline Equation: Untitled & & & \\
\hline Test Statistic & Value & df & Probability \\
\hline F-statistic & 9.290471 & $(9,17)$ & 0.0001 \\
Chi-square & 83.61424 & 9 & 0.0000 \\
\hline
\end{tabular}

Null Hypothesis:

$\mathrm{C}(11)=\mathrm{C}(12)=\mathrm{C}(13)=\mathrm{C}(14)=\mathrm{C}(15)=\mathrm{C}(16)=\mathrm{C}(17)=\mathrm{C}(18)=\mathrm{C}(19)=0$
**The bounds critical values which are obtained from Pesaran et al [27] are 2.22 and 3.39 as the lower and upper values respectively when the number of variables is 8 and the level of significance is $5 \%$. From the bounds test above, we observe that calculated $\mathrm{F}$ value is greater than the upper critical value from the Pesaran table. We therefore fail to accept the null hypothesis that there is no long run equilibrium relationship between price level variable and the other variables but rather uphold the alternative hypothesis that there exists a long run co integrating relationship in our model.

At the next stage of the estimation, we set out to determine the long run equilibrium equation. The estimated equation is presented below.

Table 6. Long run equilibrium equation.

\begin{tabular}{|c|c|c|c|c|}
\hline \multicolumn{5}{|c|}{ Dependent Variable: LCPI } \\
\hline \multicolumn{5}{|c|}{ Included observations: 38} \\
\hline Variable & Coefficient & Std. Error & t-Statistic & Prob. \\
\hline $\mathrm{C}$ & 174.7064 & 29.20014 & 5.983068 & 0.0000 \\
\hline LEX_R & 0.088355 & 0.093136 & 0.948663 & 0.3506 \\
\hline $\mathrm{LFP}^{\mathrm{C}}$ & -0.010571 & 0.004483 & -2.358146 & 0.0306 \\
\hline LGDP2 & -1.580403 & 0.213230 & -7.411711 & 0.0000 \\
\hline LMS & 0.350389 & 0.170389 & 2.056403 & 0.0488 \\
\hline $\mathrm{LC}^{\mathrm{P}}$ & 0.921535 & 0.477481 & 1.928950 & 0.0557 \\
\hline $\mathrm{LP}^{\mathrm{P} *}$ & 11.32951 & 1.896521 & 5.973838 & 0.0000 \\
\hline $\mathrm{R}$ & -0.002945 & 0.003167 & -0.929848 & 0.3601 \\
\hline R-squared & 0.998525 & Durbin-Watson stat & & 1.806430 \\
\hline F-statistic & 2454.714 & & & \\
\hline Prob(F-statistic) & 0.000000 & & & \\
\hline
\end{tabular}

To measure the short-run relationship we introduce an error correction term derived from the residuals into our lagged model. The results are displayed in the table below.

Table 7. Error correction model.

\begin{tabular}{|c|c|c|c|c|}
\hline \multicolumn{5}{|c|}{ Dependent Variable: D(LCPI) } \\
\hline \multicolumn{5}{|c|}{ Included observations: 35 after adjustments } \\
\hline Variable & Coefficient & Std. Error & t-Statistic & Prob. \\
\hline $\mathrm{C}$ & -0.339723 & 0.181742 & -1.869260 & 0.0738 \\
\hline D(LCPI(-1)) & 0.655615 & 0.328839 & 1.993723 & 0.0577 \\
\hline $\mathrm{D}\left(\operatorname{LFP}^{\mathrm{C}}(-1)\right)$ & -0.262836 & 0.083552 & -3.145767 & 0.0044 \\
\hline D(LEX_R(-1)) & 0.220364 & 0.086738 & 2.540571 & 0.0180 \\
\hline $\mathrm{D}\left(\mathrm{LI}^{\mathrm{M}}(-1)\right)$ & -0.287443 & 0.080915 & -3.552419 & 0.0016 \\
\hline D(LMS(-1)) & 0.551742 & 0.224972 & 2.452497 & 0.0218 \\
\hline $\mathrm{D}\left(\mathrm{LP}^{\mathrm{P} *}(-1)\right)$ & 17.14444 & 7.968638 & 2.151489 & 0.0417 \\
\hline $\mathrm{D}(\mathrm{LCP}(-1))$ & 0.182356 & 0.088855 & 2.052275 & 0.0559 \\
\hline D(LGDP2(-1)) & -1.030966 & 0.384375 & -2.682188 & 0.0157 \\
\hline $\mathrm{D}(\mathrm{R}(-1))$ & 0.001295 & 0.003868 & 0.334873 & 0.7406 \\
\hline ЕСТ(-1) & -0.595345 & 0.263119 & -2.262646 & 0.0330 \\
\hline R-squared & 0.636737 & \multirow{4}{*}{\multicolumn{2}{|c|}{ Durbin-Watson stat }} & 1.883018 \\
\hline Adjusted R-squared & 0.485378 & & & \\
\hline F-statistic & 4.206788 & & & \\
\hline Prob(F-statistic) & 0.001894 & & & \\
\hline
\end{tabular}

Table 8. Final test for serial correlation in model.

\begin{tabular}{|c|c|c|c|}
\hline \multicolumn{4}{|c|}{ Breusch-Godfrey Serial Correlation LM Test: } \\
\hline F-statistic & 0.785246 & Prob. F(1,23) & 0.3847 \\
\hline Obs*R-squared & 1.155490 & Prob. Chi-Square (1) & 0.2824 \\
\hline
\end{tabular}

*This shows that there is no serial correlation in the final model. 


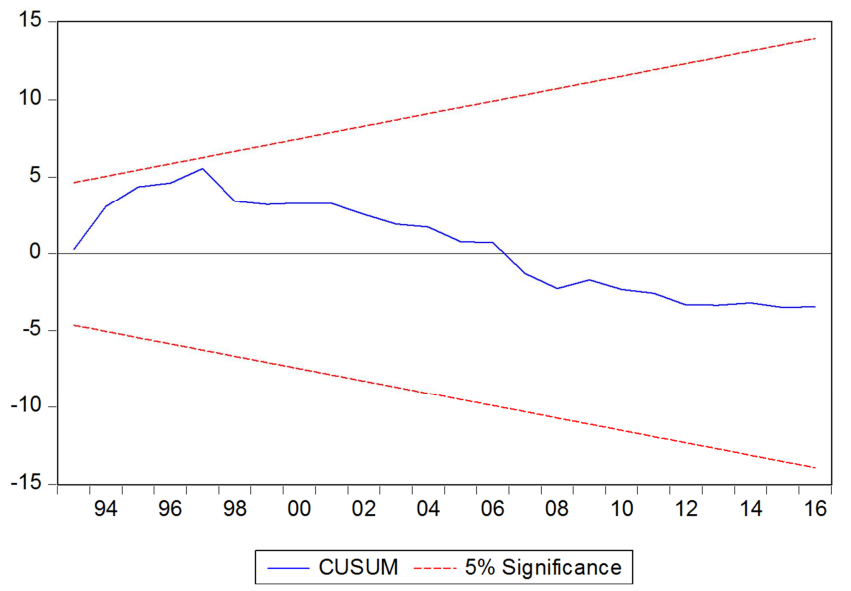

Figure 2. FINAL STABILITY TESTS (CUSUM).

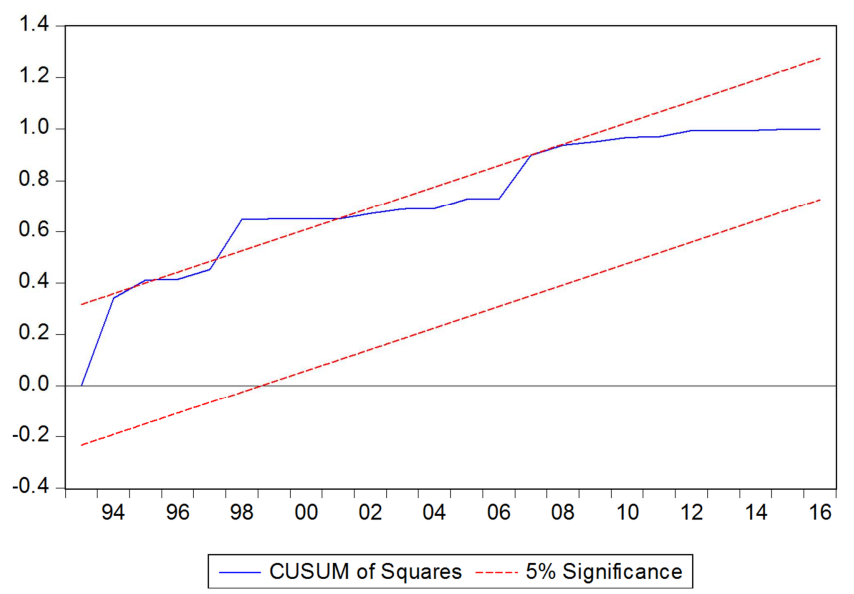

Figure 3. CUSUM (Q) test.

*Figures 2 and 3 show that our final model is relatively stable.

From the long run equation in table 6 we observe that five of the eight variables exert significant impacts on the price level variable in the long run. Of these, the variables having the most significant impact on price level are growth in output and population growth in the country. Their measured impacts are $-1.58 \%$ and $11.3 \%$ of change in price level with respect to a unit increase in each of the variables at less than $1 \%$ level of significance. The signs returned by these variables are also consistent with our expectation. The positive impact of population growth on the price level variable is consistent with the study, Enu and Havi [12]. The measured negative impact of the growth in output confirms the result obtained by, Chiaraah and Nkegbe [13]. The long run effect of the money supply on price level in our equation also buttresses Chiaraah and Nkegbe [13]. More succinctly, from the estimates, a $100 \%$ increase in money supply triggers about $35 \%$ increase in price levels.

The variables which do not impact significantly on price level in the long run are exchange rate, imports and the policy rate.

From the short run equation or the error correction model, we find that speed of adjustment of the system is about $60 \%$ meaning that $60 \%$ of the deviation of the system from the equilibrium position in every period is corrected. This speed of adjustment is lower than that of the study by Chiaraah and Nkegbe [13] with $85 \%$, correction but higher than these studies;Elgammal and Eissa and Akinbobola [6-7] whose speeds of adjustment were estimated to be $2 \%$ and $3.6 \%$ per period respectively.

The feedback effect of price level is expectedly positive whilst in the short run; the proxy for food production has a negative effect on current price level. The estimated short run effect of growth in output on current price level is negative and this is in line with both these studies; Elgaammal and Eissa and Chiaraah and Nkegbe $[6,13]$. In precise terms, a percentage increase in past output in the economy precipitates about $1.03 \%$ increase in current inflation.

Surprisingly however, the effect of past values of imports on current price level is negative implying that an increase in past imports rather leads to a decline in current price level. It is surprising because generally price of imports trend upwards rather than downwards especially for an import dependent economy like that of Ghana hence we expect imports to propel current inflation on an increasing trajectory.

Expectedly, the impact of past growth in money supply on current price level is positive. This contrasts with Elgaammal and Eissa and Chiaraah and Nkegbe $[6,13]$ who could not establish short run effect of past money supply on current inflation. In actual terms from our results, a $100 \%$ increase in past money supply triggers about 55\% upswing in current price level.

Another interesting but expected result is the estimated impact of the past values of prices of crude oil on the world market on present price level. Unlike Elgammal and Eissa [6] who did not find any significant impact of past values of world crude prices on current price level, our short-run estimates show that a $100 \%$ increase in past price of crude oil leads to about $18 \%$ increase in present price level. This is expected because the price of crude oil is something that has a cascading effect on the Ghanaian economy and indeed it always takes time for the effect of the change in international price of crude oil to be fully transmitted into the economy. Finally, just as found in the study by Elgammal and Eissa [6], we discover from our short-run analysis that the rate of interest rate proxied by the policy rate does not exert a significant impact on the present price level.

\section{Conclusions and Policy Implications}

The main preoccupation of this study has been to identify both the structural and monetary determinants of price level movements in Ghana employing the dynamic ARDL method for the first time on the Ghanaian situation and also comprehensively bringing into the analysis the effects of crude oil prices, food production in the country, population growth as well imports into the Ghanaian economy.

The unit roots tests confirmed that all the variables in our model are integrated of order less than two which situation 
satisfies the precondition for ARDL estimation. The Wald (bounds) test indicates a long run equilibrium relationship price level and the other variables in the model. Generally, we have confirmed that in the movements of the price level in Ghana, both structural and monetary factors are at play. In fact our results suggest that growth in food production represented by cereal production and general output in Ghana are key structural factors which significantly affect current price level in the Ghanaian economy. They can therefore not be ignored when it comes to dealing with the phenomenon of inflation in Ghana.

Again our estimates reveal a strong impact of crude oil prices on the inflationary process in Ghana in both the long and short runs but the impact of exchange rate on current price level is only experienced in the short-run. Our findings with respect to money also confirm that in both the long and short runs money supply also reinforces and propels the inflationary pressures in the economy.

It is also important to note that our estimations clearly reveal that the inflationary movements in Ghana are influenced by both domestic and external factors.

For purposes of policy designing, we recommend that in fighting inflation, policy makers do not become only fixated with the monetary prescriptions which have become the orthodox approach but also pay attention to the structural aspects of the economy especially the issues of food production and the real side of the economy which relates to the generation of goods and services. In particular all sources of rigidities in the production sectors both on the real or the food production side should be tackled and addressed.

In respect of crude oil prices dealing with that is always a challenge; this is because these are exogenously determined. However policy makers can only seek to mitigate their effects by assiduously working to identify other sources of energy in order to reduce their cascading effects on the general price level within the Ghanaian economy.

Lastly the issue of the effect of the exchange rate depreciation would largely be taken care when the real side problems are addressed; in particular bottlenecks of production should be looked at and value addition to traditional exports aside of the identification of other export products should vigorously be pursued to be able to reduce pronounced excess demand for foreign currencies over their supply which situation fuels depreciation of the Ghana Cedi and eventually transmits upward pressure on prices in the economy.

In sum we say that though in this study we have endeavoured to be as comprehensive in our analysis as possible we acknowledge that, we could not tackle all the relevant factors which could possibly be covered; in particular the inflationary precipitating factors which may emerge from the fiscal side of the Ghanaian economy were not captured in our model therefore it is suggested that future studies should broaden the scope by encompassing these factors.

\section{References}

[1] Hossain, M., J., \& Islam, N. (2013). An economic analysis of the determinants of inflation in Bangladesh. The International Journal of Social Sciences, 11 (1).

[2] Kandil, M., \& Morsy, H. (2009). Determinants of inflation in GCC. International Monetary Fund (IMF) Working Paper, $\mathrm{WP} / 09 / 82$.

[3] Lim, C., H., \& Papi, L. (1997). An econometric analysis of determinants of inflation in Turkey. IMF Working paper, 97/170, Washington DC.

[4] Bashir, F., Nawaz, S., Yasin, K., Khursheed, U., Khan, J., \& Qureshi, M., J. (2011). Determinants of inflation in Pakistan: an econometric analysis using Johanssen co-integration approach. Australian Journal of Business and Management, 1 (5), 71-82.

[5] Hashim, M., J., Osman, I., \& and Elias, N., L. (2014). The determinants of inflation in Malaysia. Presented at $3^{\text {rd }}$ International Conference on Accounting, Business and Economics (ICABEC), 2014.

[6] Elgammal, M., M., \& Eissa, M., A. (2015). Key determinants of inflation and monetary policy in the emerging markets: evidence from Vietnam. Afro-Asian Journal of Finance and Accounting, $\mathrm{X}(\mathrm{Y})$.

[7] Akinbobola, T., O. (2012). The dynamics of money supply exchange rate and inflation in Nigeria. Journal of Applied Finance and Banking, 2 (4).

[8] Kwakye, J., K. (1981). An econometric analysis of price behavior. University of Ghana Thesis.

[9] Chhibber, A., \& Shafik, N. (1990). Exchange reform parallel market and inflation in Africa: the case of Ghana. World Bank Working Paper (WPS427). Washington DC: World Bank.

[10] Sowa, N., K., \& Kwakye, J., K. (1993). Inflationary trends and control in Ghana. African Economic Research Consortium $(A E R C)$, Research Paper 22, Nairobi, Kenya.

[11] Gyebi, F., \& Boafo, K., G. (2013). Macroeconomic determinants of inflation in Ghana from 1990-2009. International Journal of Business and Social Research, 3 (6).

[12] Enu, P., \& Havi, D., E. (2014). Macroeconomic determinants of inflation in Ghana: A co integration approach. International Journal of Academic Research in Business and Social Sciences, 4 (7).

[13] Chiaraah, A., \& Nkegbe, P., K. (2014). GDP growth, money growth, exchange rate and inflation in Ghana. Journal of Contemporary Issues in Business Research, 3 (2).

[14] Acquah-Sam, E. (2017). Influencers of inflation in Ghana. European Scientific Journal, March edition 13 (7).

[15] Sanusi, A., R. (2010). Exchange rate pass through to consumer prices in Ghana: Evidence rate pass through to consumer prices in Ghana: evidence from structural vector auto regression. Journal of Econometrics, 3 (3).

[16] Sahminan, S. (2002). Exchange rate pass through into import prices: empirical evidences from South East Asian countries. Journal of Economic Research, 2 (4). 
63 Emmanuel Atta Anaman: Examining the Factors Underlining the Inflationary Phenomenon in Ghana - A Dynamic ARDL Analysis

[17] Sargent, T., J., \& Wallace, R. (1981). Some unpleasant monetarist arithmetic. Quarterly Review, Federal Reserve Bank of Minneapolis, Fall Issue.

[18] Montiel, P., J. (1989). Empirical analysis of high-inflation episodes in Argentina, Brazil and Israel. IMF Staff Papers, 3, 527-49.

[19] Lissovolik, B. (2003). Determinants of inflation in a transition economy: the case of Ukraine. IMF Working Paper, European II Department.

[20] Granger, C., W., J., \& Newbold, P. (1974). Spurious regression in econometrics. Journal of Econometrics, 2 (2), 111-120.

[21] Harris, R., \& Sollis, R. (2003). Applied time series modelling and forecasting. United Kingdom: Wiley Press.

[22] Thomas, R., L. (1993). Introductory economics: theory and applications. ( $2^{\text {nd }}$ ed.). London, UK: Longman Press.
[23] Anaman, E., A., Gadzo, S., G., Gatsi, J., G., \& Pobbi, M. (2017). Fiscal aggregates government borrowing and economic growth in Ghana: an error correction approach. Advances in Management and Applied Economics, 7 (2), 83104.

[24] Pesaran, M., H., \& Pesaran, B. (1997). Working with microfit 4.0: international econometric analysis. Oxford: Oxford University Press.

[25] Banerjee, A., Dolado, J., Galbraith, J., \& Hendry, D. (1993). Co integration, error correction and econometric analysis of non-stationary data. Oxford: Oxford University Press.

[26] Frimpong, J., M., \& Oteng-Abayie, E., F. (2006). Bounds testing approach: an examination of direct investment, trade and growth relationship. MPRA Paper, 352.

[27] Peasaran, M. H., Shin, Y. and Smith, R. J. (2001). Bounds testing for Relationships. Journal of Applied Econometrics, Vol 16 (3) pp 289-326. 